\title{
Nature and Nurture Resolved
}

\author{
James F Welles* \\ East Marion, New York, USA
}

Submission: August 28, 2017; Published: September 07, 2017

*Corresponding author: James F Welles, PO Box 17, East Marion, New York, USA, Tel: 631-323-8153, 954-531-5382; Email: JWelles103@aol.com

\section{Opinion}

The ageless faux controversy of nature v. nurture continues to haunt the otherwise scientific literature of behavioral biology. One classic example-the evolutionary value of the opposable thumb-encapsulates the essence of unnecessarily conflicting attitudes in this useless confrontation.

The standard saw offered by anatomists is that the pseudo-opposable thumb of New World anthropoids (e.g., Cebus) monkeys is mechanically limited to movements in one dimension-left and right-and thus limits the behavioral range of monkeys condemned to secondary evolutionary status by this structural inhibition. By way on contrast, Old World anthropoids were blessed with opposable thumbs which permitted swivelling action which in turn opened the way for humans to develop tool use as the pathway to biological predominance. Unfortunately, this is not true.

A concerted study of manual prehension in anthropoids-a battery of tests examining eight different aspects of graspingproved that while humans (Homo), with opposable thumbs, are superior to all other species in grasping objects, the second best genus was Cebus, with their supposedly limiting pseudoopposable joint. Next in efficiency were opposable thumbed Pan (chimps) and some Old World monkeys (Rhesus and Patas) and then some pseudo-opposed species Saimiri (squirrel monkeys) and Callimicos. Skipping the fact that perhaps humans were superior because a human created the tests, Cebus monkeys were the curve-busters. But for them, the anatomists would have been correct; the opposable thumb is an enabler, and pseudoopposable thumbs a limitation. However, the fact remains, the Cebus monkeys (think organ-grinder partners) out performed all non-human genera tested.
How can this be? The answer is in the life style of Cebus. In their natural habitat, they are actively engaged in interacting with their environment. One example should suffice to make the point. When discovering a stump invested with edible termites, a Cebus monkey will tear apart the decaying wood to convert the insects into food. When placed in a cage which is held shut by a chain tightly tied by a handler but within reach of the imprisioned animal, it deftly unties the chain and escapes. These are the monkeys trained to assist quadriplegics: upon verbal request/ command, they will open a refrigerator door, take out a bottle of soda pop, open it, put a straw in it and place so the patient can sip it. They are as intelligent as they are deft in using their hands.

So, among anthropoids, nurture (life experience) trumps nature (genetics). If we place anthropoids at one end of a continuum-say in the left side, all other forms of animal life can be strung along to the opposite end where on finds instinct driven insect and arachnids. Anthropoids, and other mammalian genera, produce few offspring per generation, and those few develop slowly and learn to interact with their environments. At the other extreme, insects, other invertebrates and perhaps even some fishes, produce prodigious numbers of offspring per generation, but their behavioral repertoires are extremely limited. The young develop rather quickly, with essentially no learning along the way. Survival is usually assured by the vast numbers of siblings, only two of which need to survive to reproduce and continue the genetic line.

Thus, nurture (learning) reigns among anthropoids and nature (genetics) at the other extreme where simple instinctive patterns of behavior suffice for survival of the species. 
(C) (i) This work is licensed under Creative Commons Attribution 4.0 Licens
Your next submission with Juniper Publishers will reach you the below assets

- Quality Editorial service

- Swift Peer Review

- Reprints availability

- E-prints Service

- Manuscript Podcast for convenient understanding

- Global attainment for your research

- Manuscript accessibility in different formats

( Pdf, E-pub, Full Text, Audio)

- Unceasing customer service

Track the below URL for one-step submission https://juniperpublishers.com/online-submission.php 